\title{
Konstribusi Lembaga Swadaya Masyarakat dalam Penanganan HIV-AIDS di Kota Kendari :Studi Pada Lembaga Advokasi HIV- AIDS Sulawesi Tenggara
}

\author{
Ayi Nur Fauziah ${ }^{1}$; Muhammad Amir' ${ }^{2}$ Muhammad Yusuf ${ }^{3}$ \\ ${ }^{123}$ Universitas Halu Oleo, ayinurfz@gmail.com
}

\begin{abstract}
Abstrak
Tujuan penelitian ini adalah untuk mengetahui bagaimana peran lembaga swadaya masyarakat dalam penanganan HIV-AIDS di Kota Kendari dan untuk mengetahui bagaimana penanganan Lembaga Swadaya Masyarakat dalam menangani HIV-AIDS di Kota Kendari. Subyek dalam penelitian ini adalah Pengurus Laha Sultra yang terdiri dari Direktur Laha, Staf Laha, ODHA Di Kota Kendari, Masyarakat ODHA,Aparat Dinas Sosial,dan Aparat Dinas Kesehatan. Tipe penelitian yang digunakan adalah deskriptif kualitatif.. Hasil penelitian menunjukkan bahwa LSM LAHA berperan seabagai Fasilitator, Broker, Mediator, Pembela, Pelindung dalam menangani HIV-AIDS di kota Kendari, Program Penanganan HIV-AIDS yaitu meningkatkan Komunikasi, Informasi dan Edukasi HIV-AIDS, meningkatkan upaya penurunan prevalensi penyakit infeksi menular seksual, meningkatkan kewaspadaan universal di saranan pelayanan kesehatan dan kerjasama antara Pemerintah Kota Kendari dengan LSM LAHA masih kurang dalam penanggulangan HIV-AIDS yang terjadi di Kota Kendari.
\end{abstract}

Kata kunci : Peran, Penanganan, HIV-AIDS, LSM, Laha.

\begin{abstract}
The purpose of this study was to determine how the role of NGOs in handling HIV-AIDS in Kendari City and to find out how to handle NGOs in handling HIV-AIDS in Kendari City. The subjects in this study were the Southeast Sulawesi Province Board of Directors consisting of the Director of Laha, Laha Staff, PLWHA in Kendari City, PLWHA Community, Social Service Apparatus, and Health Service Apparatus The type of research used is descriptive qualitative. The results of the research show that NGO LAHA plays a role as a Facilitator, Broker, Mediator, Defender, Protector in Dealing with HIV-AIDS In the city of Kendari, the HIV-AIDS Management Program, namely Improving Communication,. Information and Education of HIV-AIDS, increases efforts to reduce the prevalence of infectious diseases sexually, increasing universal awareness in the provision of health services and cooperation between the Kendari City Government and the NGO LAHA still lacking in the handling of HIV-AIDS that occurred in Kendari City.

Keywords :, Handling, HIV-AIDS, NGO, Laha. Role
\end{abstract}

\section{Pendahuluan}

Salah satu tugas pokok negara dan pemerintah adalah memajukan kesejahteraan sosial. Kesejahteraan sosial menunjuk pada keadaan sejahtera dari orang-orang di dalam masyarakat secara umum. Sedangkan kesejahteraan adalah kondisi terpenuhinya kebutuhan material dan nonmaterial antara lain kebutuhan dasar akan gizi, kesehatan, pendidikan, tempat tinggal, pendapatan dan 
perlindungan dari resiko-resiko kritis yang mengancam kehidupannya. Kesejahteraan sosial mempunyai tiga pilar utama, yakni terkendalinya masalahmasalah sosial, terpenuhinya kebutuhan-kebutuhan dasar, dan tersedianya kesempatan-kesempatan untuk maju. Pemerintah perlu memajukan kesejahteraan umum karena setiap warga negara memerlukan suatu level tertentu kesejahteraan untuk dapat melaksanakan fungsi sosialnya. Dalam rangka memajukan kesejahteraan umum sebagaimana dimaksud di atas, pemerintah menyelenggarakan kesejahteraan sosial. Penyelenggaraan kesejahteraan sosial adalah upaya yang terarah, terpadu, dan berkelanjutan yang dilakukan oleh pemerintah, pemerintah daerah, dan masyarakat, guna memenuhi kebutuhan dasar setiap warga negara. Lingkup penyelenggaraan kesejahteraan sosial, berdasarkan Peraturan Pemerintah Nomor 39 Tahun 2012 Tentang Penyelenggaraan Kesejahteraan Sosial, meliputi rehabilitasi sosial, jaminan sosial, pemberdayaan sosial, dan perlindungan sosial. Penyelenggaraan kesejahteraan sosial menjadi tanggung jawab utama pemerintah dan pemerintah daerah. Namun demikian, masyarakat dituntut untuk berperan serta secara aktif di dalam proses tersebut. Hal ini sesuai dengan teori pembangunan partisipatif dari Conyers (dalam Ningsih, 2013:14) yang mengatakan bahwa merupakan suatu hak demokrasi bila masyarakat dilibatkan dalam pembangunan masyarakat sendiri. Selain itu, manfaat penyelenggaraan kesejahteraan sosial diharapkan dapat menjangkau seluruh warga negara. Akan tetapi, Peraturan Pemerintah Nomor 39 Tahun 2012

Tentang Penyelenggaraan Kesejahteraan Sosial, memberikan prioritas kepada mereka yang memiliki kehidupan yang tidak layak secara kemanusiaan dan memiliki kriteria masalah sosial. Kelompok tersebut lebih dikenal dengan Penyandang Masalah Kesejahteraan Sosial (PMKS), yakni seseorang, keluarga atau kelompok masyarakat yang karena suatu hambatan, kesulitan atau gangguan, tidak dapat melaksanakan fungsi sosialnya, sehingga tidak dapat terpenuhi kebutuhan hidupnya (jasmani, rohani, dan sosial) secara memadai dan wajar.

Salah satu kategori PMKS adalah Orang dengan HIV/AIDs atau lazim disingkat ODHA, yakni suatu sebutan bagi orang-orang yang telah terjangkit penyakit HIV/AIDS Dalam kenyataan, pada umumnya ODHA kurang mendapat 
tempat yang layak di masyarakat, tidak memandang apapun profesi dan pekerjaannya. Mereka dikucilkan dan dikecam dilingkungannya, bahkan tidak sedikit ODHA dikucilkan oleh keluarganya sendiri. Respon masyarakat terhadap ODHA sangat negatif, masyarakat menganggap adanya ODHA di lingkungan mereka membahayakan. Dengan kondisi tersebut, harapan hidup ODHA tidak sama lagi dengan orang-orang normal pada umumnya. Mereka terpinggirkan dan seakan telah mati sebelum nyawanya berpisah dengan tubuh. Banyak masyarakat yang memberikan stigma terhadap ODHA (Shaluhiyah, dkk., 2015:333).

Stigma terhadap ODHA tergambar dalam sikap sinis, perasaan ketakutan yang berlebihan, dan pengalaman negatif terhadap ODHA. Hal inilah yang menyebabkan ODHA menerima perlakuan yang tidak adil, diskriminasi, dan penolakan dalam pelbagai lingkup kegiatan kemasyarakatan seperti dunia pendidikan, dunia kerja, dan layanan kesehatan. Idealnya, ODHA tetap diajak bergaul, dimanusiakan agar mereka bisa kembali bersemangat menghadapi sisasisa hidupnya, dibantu dan turut menyemangati hidupnya sehingga menjadi lebih semangat dan optimis. Bahkan, peraturan perundang-undangan menjamin ODHA berhak untuk mendapat pendampingan agar mereka mendapatkan perawatan yang lebih baik .Dalam pendampingan terhadap ODHA, masyarakat seharusnya berperan sebagai fasilitator, broker, mediator, pembela, dan pelindung (Latifah dkk., 2017:307-310). Meski demikian, masih sedikit yang kita ketahui tentang bagaimana seluruh elemen masyarakat sesuai kapasitasnya masing-masing memainkan peran-peran tersebut dalam penanganan ODHA.

Fenomena kehidupan yang tidak layak secara kemanusiaan dan memiliki kriteria masalah sosial sebagaimana diuraikan di atas, khususnya ODHA, juga ditemukan di Kota Kendari Provinsi Sulawesi Tenggara. Data dari Dinas Kesehatan Provinsi Sulawesi Tenggara menyebutkan bahwa dari 2004 sampai 2015 terdapat sebanyak 282 orang ODHA (Anonim, 2017:1). Selanjutnya, sumber berita online sultra.antaranews.com edisi Selasa, 7 Agustus 2018, menyebutkan bahwa Dinas Kesehatan Provinsi Sulawesi Tenggara selama 2017 menemukan sebanyak 861 kasus yang pengidap HIV-AIDS. Dari jumlah tersebut, yang terbanyak berada di Kendari, yakni sebanyak 257 kasus (Anonim, 2018:1).Sumber di atas menyebutkan 
pula bahwa ODHA di Sulawesi Tenggara terus meningkat dari tahun ke tahun. Akan tetapi, menurut salah seorang sumber informasi, ODHA ibarat fenomena gunung es, yaitu jumlah penderita yang dilaporkan jauh lebih kecil daripada jumlah penderita yang sebenarnya. Dengan begitu, jumlah ODHA yang ada di Kota Kendari yang sebenarnya belum akurat namun dapat dipastikan angkanya jauh lebih besar daripada jumlah yang telah dilaporkan dan di identifikasi oleh instansi pemerintah daerah (wawancara dengan MN, tanggal 11 Maret 2019).

Masyarakat di Kota Kendari telah menunjukkan peran sertanya dalam penanganan PMKS khususnya ODHA sebagai bagian dari usaha penyelenggaraan kesejahteraan sosial. Hal tersebut ditunjukkan antara lain oleh Lembaga Swadaya Masyarakat (LSM) Lembaga Advokasi HIV-AIDSSulawesi Tenggara, atau lebih dikenal dengan LAHA Sultra. LSM tersebut didirikan pada tahun 2004 berdomisili di Kota Kendari. Visi LAHA Sultra adalah menjadi LSM yang terdepan dalam penanggulangan HIV/AIDS berbasis pemberdayaan ODHA dan Kelompok Risiko Tinggi. Sedangkan Misi LAHA Sultra adalah memberikan pendampingan dan dukungan kepada ODHA dan keluarganya serta menjadi mitra pemerintah dalam upaya penanggulangan HIV/AIDS khususnya di Sulawesi Tenggara (wawancara dengan MN, tanggal 11 Maret 2019).

Sejak berdirinya sampai sekarang LSM LAHA Sultra telah melaksanakan beragam upaya pemberdayaan yang terprogram dalam upaya penanggulangan HIV/AIDS di berbagai daerah di Sulawesi Tenggara dan yang lebih dominan kegiatannya adalah di Kota Kendari. Dalam periode waktu tahun 2005 sampai 2008, LAHA Sultra berperan sebagai mitra pemerintah Kota Kendari dalam melakukan kegiatan danprogram komunikasi, informasi dan edukasi tentang HIV/AIDS (Masudin, 2008:1). Selanjutnya, dalam periode sampai dengan 2018, LAHA Sultra menjalin kerjasama yang bersifat kemitraan dengan Komisi Penanggulangan AIDS Nasional (KPAN), Kementerian Kesehatan, Badan Pemberdayaan Perempuan, dan Kementerian Sosial. Selain itu, program LAHA Sultra dalam memberdayakan ODHA mendapat dukungan pendanaan dari LSM dunia di Genewa Swiss, yakni the Global InnovationFun (GIF). Namun, nota 
kesepahaman LAHA Sultra dengan GIF untuk dukungandana tersebut hanya sampai tahun 2015 (wawancara dengan MN, tanggal 11 Maret 2019).

Peran serta LAHA Sultra dalam penanganan PMKS khususnya dalam pendampingan terhadap ODHA di Kota Kendari idealnya mencakup peran sebagai fasilitator, broker, mediator, pembela, dan pelindung. Peran-peran tersebut sangat diharapkan oleh masyarakat karena: pertama, meningkatnya fenomena ODHA di Kota Kendari dalam beberapa tahun terakhir; kedua, masih kuatnya stigma terhadap ODHA yang berdampak buruk pada kehidupan dan kondisi kesejahteraan mereka; dan ketiga, masyarakat mempunyai tanggung jawab untuk bersama-sama pemerintah melakukan penyelenggaraan kesejahteraan sosial. Namun demikian, sampai sekarang belum ada analisis empiris yang komprehensif tentang peran LSM tersebut. Berdasarkan alasan-alasan sebagaimana yang telah diuraikan di atas maka penulis tertarik untuk mengusulkan penelitian dengan judul "Peran Lembaga Swadaya Masyarakat Dalam Penanganan HIV-AIDS di Kota Kendari (Studi Pada Lembaga Advokasi HIV-AIDS Sulawesi Tenggara)." tujuan penelitian ini adalah untuk mengetahui Bagaimana Peran Lembaga Swadaya Masyarakat Dalam Penanganan HIV-AIDS di Kota Kendari Untuk mengetahui bagaimana Penanganan Lembaga Swadaya Masyarakat Dalam Menangani HIVAIDS di Kota Kendari.

\section{Metode}

Lokasi penelitian ini adalah pada Lembaga Swadaya Masyarakat (LSM) Lembaga Advokasi HIV-AIDS Sulawesi Tenggara (LAHA Sultra) di BTN Meddy Brata Blok.B/16 Kendari Permai. Alasan pemilihan lokasi tersebut adalah karena telah mengembangkan kemitraan dengan pemerintah Kota Kendari dan instansi terkait lainnya dalam memberikan pendampingan kepada ODHA di Sulawesi Tenggara. Jenis penelitian ini adalah deskriptif dengan pendekatan kualitatif. Dengan jenis deskriptif maka penelitian ini akan berusaha untuk mendeskripsikan fakta atau fenomena peran LSM dalam penanganan masalah ODHA pada lokasi yang telah disebutkan di atas. Selanjutnya, dengan pendekatan kualitatif maka penelitian ini berusaha memahami dan menginterpretasikan fenomena tersebut 
dalam konteks alamiah di mana personil LSM melaksanakan perannya dalam penanganan masalah ODHA. Dengan pendekatan kualitatif, peneliti berusaha mengumpulkan dan menyajikan data yang terutama berbentuk data visual dan verbal. Adapun datayang berbentuk angka hanyalah menjadi pendukung dalam rangka menjustifikasi kesimpulan penelitian. diperlukan. Informan penelitian sebanyak 5 orang yang terdiri dari:

1) Personil LSM LAHA Sultra sebanyak 3 orang.

2) Aparat Dinas Sosial sebanyak 2 Orang

3) Aparat Dinas Kesehatan sebanyak 2 orang

4) ODHA di Kota Kendari yang mendapatkan penanganan, sebanyak 3 orang.

5) Warga masyarakat keluarga ODHA di Kota Kendari, sebanyak 2 orang.

\section{Hasil dan Pembahasan}

Lembaga Swadaya Masyarakat (LSM) Lembaga Advokasi HIV-AIDS Sulawesi Tenggara, atau lebih dikenal dengan LAHA Sultra didirikan pada tahun 2004 berdomisili di Kota Kendari. Visi LAHA Sultra adalah menjadi LSM yang terdepan dalam penanggulangan HIV/AIDS berbasis pemberdayaan ODHA dan Kelompok Risiko Tinggi. Sedangkan Misi LAHA Sultra adalah memberikan pendampingan dan dukungan kepada ODHA dan keluarganya serta menjadi mitra pemerintah dalam upaya penanggulangan HIV/AIDS khususnya di Sulawesi Tenggara yang berlokasi di BTN Meddy Brata Blok.B/16 Kendari Permai.

Meningkatnya kecepatan penyebaran HIV/AIDS, terutama pada ke kelompok risiko tinggi, mendapat perhatian pemerintah. Tanggapan nasional terhadap tingginya tingkat penyebaran penyakit ini adalah cerminan dari komitmen internasional, khususnya Declaration of Commitment pada UNGASS HIV/AIDS 2001, Deklarasi ASEAN tentang HIV/AIDS 2001 dan Deklarasi A World Fit of Children 2002. Bentuknyata kepedulian pemerintah untuk menanggulangi penyebaran HIV/AIDS di Indonesia adalah dengan dibentuknya Komisi Nasional. Pencegahan Penanggulangan AIDS berdasarkan Keppres Nomor 36/1994 yang diketuai oleh Menko Kesra dengan anggota beberapa menteri dan kepala lembaga 
pemerintahan lain. Laporan Subdit AIDS dan PMS Departemen Kesehatan pada bulan Desember 2005 menyebutkan jumlah kasus HIV di Indonesia adalah 4.244 kasus dan AIDS berjumlah 5.321 kasus. Rasio kasus AIDS antara lakilaki dan perempuan adalah 4.5:1. Kasus AIDS terbanyak dilaporkan dari DKI Jakarta, Papua, Jawa Timur, Jawa Barat, Bali, Kepulauan Riau, Sulawesi Selatan, Sumatera Utara, Kalimantan Barat,dan Jawa Tengah. (Depkes, 2006).

Peningkatan kasus HIV di Kota Kendari mencapai 18 penderita. Data Dinas Kesehatan Sulawesi Tenggara menunjukan bahwa dalam satu tahun terakhir terjadi peningkatan yang sangat besar. Data penderita HIV/AIDS sampai dengan Juni 2007 menurut faktor risiko penularan yang terjadi di Sulawesi Tenggara khususnya di Kota Kendari yang paling drama adalah Heteroseksual sebesar 94 Sebab terjadinya peningkatan kasus HIV/AIDS di Sulawesi Tenggara Tahun 2006 telah dibentuk Komisi Penanggulangan HIV/AIDS Daerah (KPAD) Kota Kendari. Komisi ini terdiri atas beberapa instansi pelaksanaan seperti dinas kesehatan, dinas sosial, dinas agama, unit swasta, dan LSM. Komisi tersebut dipimpin oleh Walikota Kendari. Tujuan utama pembentukan komisi adalah untuk mengkoordinir dan mengkonsolidasikan upaya-upaya pencegahan dan pengendalian penyakit HIV/AIDS di Kota Kendari. Survey awal yang dilakukan peneliti pada bulan Juni tahun 2019 berhasil mengetahui bahwa kerjasama antara Pemerintah Kota Kendari dengan LSM LAHA masih kurang dalam penanggulangan HIV/AIDS yang terjadi di Kota Kendari Penelitian ini merupakan studi kasus pada LSM.

LAHA Sulawesi Tenggara dalam upaya penanggulangan HIV/AIDS di Kota Kendari. Masalah kesehatan menjadi urusan berbagai pihak yang dilaksanakan dalam bentuk kemitraan sehingga kesehatan akan menjadi bagian dari oleh dan untuk semua pihak kurangnya kerjasama dalam penanggulangan HIV/AIDS yang terjadi di Kota Kendari tidak menutup kemungkinan akan meningkat yang pada akhirnya dapat menyebabkan tingginya kematian.

\section{Peran LSM Dalam Penanganan HIV/AIDS Di Kota Kendari}

Kesejahteraan Sosial yang dibuat oleh Pemerintah Kota Kendari yang berorientasi Rehabilitasi Sosial bagi ODHA yaitu berperan sebagai fasilitator, 
perantara (broker), mediator, pembela dan pelindung. Adapun penjelasannya sebagai berikut:

\section{a. Fasilitator}

Peran LSM LAHA dalam kegiatan memfasilitasi ODHA agar mampu menangani tekanan psikis dan sosial yang dialami, dimana melibatkan ODHA sebagai penerima manfaat, agar pekerja sosial bisa mengerti tentang kebutuhan apa yang diinginkan, serta mengembangkan potensi setiap. Peran LSM LAHA sebagai fasilitator membantu ODHA dalam kegiatan pelayanan, agar kegiatan pelayanan dapat terlaksana dengan baik.

Bahwa peranan pekerja sosial sebagai fasilitator di LSM LAHA yakni memotivasi penerima dalam kegiatan pelayanan bimbingan, dengan memfasilitasi segala yang dibutuhkan penerima manfaat dalam mengembangkan potensi yang dimilikinya seperti sarana prasarana dalam semua kegiatan pelayanan bimbingan baik bimbingan fisik, kesenian, keagamaan maupun keterampilan, agar penerima manfaat lanjut usia menjadi pribadi yang berguna bagi dirinya sendiri maupun di masyarakat khususnya di dalam unit keluarga ODHA.

\section{b. Perantara (broker)}

Peran LSM LAHA sebagai perantara (broker) yang ada sangat erat dengan upaya menghubungkan individu maupun kelompok yang membutuhkan bantuan ataupun pelayanan, tetapi tidak tahu dan bagaimana mendapatkan bantuan tersebut dengan lembaga yang menyediakan pelayanan. Bahwa peranan LSM LAHA sebagai perantara, yaitu membantu dan memudahkan masyarakat khususnya penerima penanganan yang memiliki keluarga maupun tidak memiliki keluarga dan dalam keadaan terlantar serta memerlukan/ membutuhkan perawatan melalui LSM LAHA sehingga masalah yang dihadapi penerima penanganan ODHA segera tertangani.

\section{c. Mediator}

Peran LSM LAHA sebagai mediator yaitu membantu menyelesaikan konflik, pertikaian ataupun perselisihan antara penerima penanganan warga ODHA. Bahwa peran pekerja sosial dalam tataran keluarga ODHA sebagai mediator harus benar-benar bisa membina atau mengkondisikan suatu 
permasalahan yang ada sehingga terjadi suatu hubungan yang baik antara pekerja sosial dengan penerima penanganan ODHA maupun antar sesama penerima penanganan.

\section{d. Pembela}

Peran LSM LAHA sebagai pembela yaitu melindungi dan membantu hak penerima manfaat lanjut usia bila dibutuhkan seperti pekerja sosial menyampaikan infomasi bagi keluarga penerima penanganan manakala akan di tempatkan di Unit rehabilitasi sosial. Dapat di jelaskan bahwa peran pekerja sosial sebagai pembela di Unit Rehabilitasi Sosial ODHA selain memberikan informasi kaitannya dengan hak penerima manfaat itu sendiri juga sebagai pemutus tindakan dalam memberikan pelayanan yang terbaik kepada penerima penanganan, dengan sumber pelayanan yang ada seperti pelayanan bimbingan fisik, mental/spiritual, bimbingan sosial, maupun bimbingan keterampilan. Peran pekerja sosial sebagai pembela di Unit Rehabilitasi Sosial kelurag ODHA yaitu sebagai pemberi informasi serta pemutus program kegiatan pelayanan yang akan diberikan kepada penerima penanganan baik itu sifatnya positif maupun tidak guna kenyamanan penerima penanganan.

\section{e. Pelindung (Protector)}

Peran pelindung yang ada di Unit Rehabilitasi Sosial kelurga ODHA ini berkaitan dengan interaksi antara pendamping dengan lembaga atas nama dan demi kepentingan penerima penanganan yang didampinginya. Pemberian perlindungan sosial dimaksudkan untuk memberikan pelayanan berupa bimbingan maupun perawatan bagi penerima penenganan tidak potensial maupun potensial agar dapat mewujudkan taraf hidupnya yang wajar. Perlindungan bagi penerima penanganan di mulai dari ditetapkannya menjadi warga di Unit Rehabilitasi Sosial keluarga ODHA sampai penerima penanganan dalam keadaan meninggal dunia.

Sebagai pengganti keluarga dari penerima penanganan yang ada di Unit Rehabilitasi Sosial keluarga ODHA, pekerja sosial selalu berupaya untuk memberikan perlindungan sesuai dengan tugas pokoknya yaitu memberikan kesejahteraan bagi penerima penanganan dalam keadaan berdaya maupun tidak berdaya misalnya ketika penerima penanganan tidak potensial terlantar yang meninggal dunia dimakamkan sesuai dengan agamanya yang mana sudah menjadi 
tanggungjawab pihak Unit Rehabilitasi keluarga ODHA jika keluarganya tidak mampu mengurus pemakamannya Peran pekerja sosial sebagai pelindung yang ada di Unit Rehabilitasi Sosial keluarga ODHA kaitannya dalam meningkatkan kesejahteraan sosial penerima penanganan yaitu dengan memenuhi kebutuhan penerima penanganan baik kebutuhan makannya, sosial, spiritual melalui pelayanan bimbingan serta melindungi penerima penanganan dalam keadaan potensial maupun tidak potensial.

\section{Upaya Lembaga Swadaya Masyarakat dalam Penanganan HIV-AIDS}

Lembaga Swadaya Masyarakat merupakan instansi yang bertanggung jawab sebagai lembaga teknis dalam melaksanakan program penanggulangan HIV dan AIDS. Secara normatif, untuk menjalankan tanggung jawab tersebut maka LSM telah menerjemahkannya dalam bentuk program-program secara umum sebagai pelaksana kebijakan HIV dan AIDS.

\section{a. Program Penanganan HIV/AIDS}

HIV/AIDS merupakan masalah kesehatan dan juga masalah sosial. Penyebaran HIV/AIDS dipengaruhi oleh perilaku manusia sehingga upaya pencegahannya perlu memperhatikan faktor perilaku. Tujuan program pencegahan adalah agar setiap orang dapat melindungi dirinya tidak tertular HIV dan tidak menularkannya kepada orang lain Adapun upaya yang dilakukan dinas kesehatan diantaranya :

a) Meningkatkan Komunikasi, Informasi dan Edukasi HIV- AIDS

Upaya meningkatkan komunikasi, informasi dan edukasi dilakukan melalui peningkatan pengetahuan, sikap dan perilaku positif dalam mencegah penularan. Kegiatan KIE diantaranya meluputi sosialisasi/ penyuluhan dan layanan komunikasi publik.

Bahwa kegiatan promosi merupakan langkah awal yang paling utama dilakukan di dalam upaya pencegahan HIV-AIDS, terlihat juga fungsi pemerintah yang dijalankan LSM yaitu memberdayakan masyarakat dengan memberikan informasi kepada masyarakat terkait pengenalan awal, cara penularan dan cara menghindari HIV-AIDS. Hal tersebut tidak lain bertujuan untuk memberi pengetahuan, dan membangun pemahaman masyarakat akan bahaya virus HIV 
AIDS sehingga dari proses pemberdayaan tersebut masyarakat dapat menjadi orang-orang yang mampu mencegah diri dari bahaya penularan HIV-AIDS. b) Meningkatkan upaya penurunan prevalensi Penyakit Infeksi Menular Seksual

Pemeriksaan kesehatan / screening IMS kelompok-kelompok beresiko Pemeriksaan kesehatan / screening. IMS bertujuan untuk mengetahui kondisi kesehatan reproduksi kalangan kelompok beresiko dalam hal menurunkan pravelensi penyakit infeksi menular seksual (IMS). Melihat upaya tersebut bahwa sudah menjadi kewajiban pemerintah dalam hal ini dinas kesehatan untuk melakukan pemantauan yang ketat terhadap kondisi kesehatan kelompok tujuannya tidak lain adalah agar kesehatan reproduksi kelompok beresiko tetap terjaga dari penyakit infeksi menular seksual. Dapat dilihat juga bahwa pemerintah telah menjalankan fungsi pengaturannya yaitu dengan adanya perda No. 3 tahun 2013 membuat kelompok-kelompok beresiko tersebut wajib untuk memeriksakan diri setiap bulan di Pusat Kesehatan Reproduksi.

c) Meningkatkan kewaspadaan universal (Universal Precaution) di sarana pelayanan kesehatan Upaya kewaspadaan universal yaitu diantaranya dilakukannya pelatihan tentang kewaspadaan universal kepada petugas kesehatan karena pekerjaannya beresiko untuk tertular HIV. Kewaspadaan universal dimaksudkan untuk melindungi petugas layanan kesehatan dan pasien lain terhadap penularan berbagai infeksi dalam darah dan cairan tubuh lain, termasuk HIV.

Upaya yang dilakukan dinas kesehatan yang bekerja sama dengan pokja HIV-AIDS yaitu dengan memberikan pelatihan kepada petugas layanan kesehatan baik di RS dan puskesmas, tentu upaya tersebut merupakan bentuk fungsi pemberdayaan yang dilakukan pemerintah dalam hal ini dinas kesehatan terhadap petugas-petugas di layanan kesehatan yang bertujuan untuk memberitahukan dan mewajibkan tindakan-tindakan yang harus dilakukan petugas kesehatan dalam penanganan kesehatan karena pekerjaan petugas kesehatan kepada pasien sangat rentan akan tertular penyakit termasuk HIV.

\section{b. Program Pencegahan LAHA}

1) Pelatihan peer education (pendidikan sebaya) 
Peer Education (pendidikan sebaya) adalah suatu proses komunikasi, informasi dan edukasi yang dilakukan oleh dan untuk kalangan yang sebaya yaitu kalangan satu kelompok, ini dapat berarti kelompok sebaya pelajar, kelompok mahasiswa, sesama rekan profesi, jenis kelamin. Kegiatan sebaya dipandang sangat efektif dalam rangka KIE penanggulangan HIV/AIDS, karena penjelasan yang diberikan oleh seseorang dari kalangannya sendiri akan lebih mudah dipahami. Pendekatan pendidikan sebaya mempunyai sejumlah keuntungan, yaitu: Pendidikan sebaya dapat menyampaikan pesan-pesan sensitif di dalamnya. Kelompok target lebih merasa nyaman berdiskusi dengan teman sebaya mengenai masalah pribadi mereka seperti seksualitas.

Berdasarkan wawancara bahwa keterlibatan LSM LAHA dengan dilakukannya pelatihan sebaya terhadap kelompok- kelompok bersiko dan para pelajar/ mahasiswa. Tentu upaya tersebut merupakan bentuk pencegahan yang dilakukan LSM dengan memberdayakan kelompok-kelompok tersebut sehinga output dari pelatihan tersebut diharapkan dapat berperan aktif dalam melakukan upaya pencegahan dan penanggulangan HIV AIDS di Kota Kendari.

\section{c. Program Dukungan}

Upaya yang dilakukan LAHA adalah memberikan dukungan terhadap ODHA dengan dilakukannya kampanye anti stigma dan diskriminasi kepada masyarakat. Tujuan dari upaya ini untuk menurunkan stigma dengan memberikan pemahaman kepada masyarakat agar tidak mempunyai presepsi buruk terhadap orang yang telah terinfeksi HIV.

Berdasarkan wawancara upaya yang dilakukan LAHA adalah memberikan dukungan terhadap ODHA dengan dilakukannya kampanye anti stigma dan diskriminasi. Tentu upaya tersebut bertujuan untuk mengurangi stigma dan diskriminasi masyarakat terhadap ODHA. Sehingga dari kampanye tersebut diharapakan masyarakat lebih peduli dengan ODHA dengan tidak melakukan tindakan diskriminatif terhadap mereka.

Program dukungan lainnya adalah LAHA melakukan pendampingan terhadap ODHA. Tujuannya adalah memperbaiki mutu hidup ODHA dengan berbagai kegiatan yang dilakukan. Berdasarkan wawancara tersebut dapat dilihat 
bahwa LAHA mempunyai peranan penting di dalam memberikan dukungan kepada ODHA, bentuk kegiatan yang dilakukan LAHA dapat simpulkan merupakan upaya rehabilitasi sosial untuk meningkatkan mutu hidup ODHA serta memberikan motivasi ODHA untuk dapat menjalani hidup seperti masyarakat pada umumnya.

\section{Hambatan dalam Penanganan HIV AIDS di Kota Kendari}

Melihat upaya Penanganan HIV AIDS di Kota Kendari tentu dalam pelaksanaannya terdapat hambatan dan tantangan yang mempengaruhi upaya tersebut, adapun hambatan dan tantangan dalam Penanganan HIV AIDS di Kota Kendari, diantaranya :

1) Rendahnya tingkat pendidikan

Tingkat pendidikan merupakan salah satu faktor yang mempengaruhi upaya dalam pencegahan dan penanggulangan HIV-AIDS di Kota Kendari. Dari hasil wawancara hambatan yang terjadi dalam upaya pencegahan dan penanggulangan HIV AIDS yaitu tingkat pendidikan masyarakat pribumi di desa misalnya yang pada umumnya hanya tamat SD bahkan ada yang tidak tamat SD, tentunya pada tingkat tersebut seseorang belum mampu menyerap dan memahami informasi dengan baik dan hal tersebut tentu menjadi hambatan terkait pemberian penyuluhan/sosialisasi atau informasi mengenai HIV/AIDS.

2) Masih kurangnya kesadaran dan pemahaman masyarakat akan bahaya virus HIV-AIDS

Pemerintah Kota Kendari telah berupaya dengan berbagai macam program pencegahan dan penanggulangan HIV AIDS. Namun yang menjadi hambatan adalah pemahaman dan kesadaran masyarakat yang dianggap kurang dalam menyikapi upaya yang telah dilakukan Laha Sultra.

Hasi wawancara diatas dapat dilihat bahwa hambatan yang terjadi adalah kurangnya pemahaman dan kesadaran masyarakat akan bahaya HIV AIDS. Pemerintah Kota Kendari telah berupaya dengan berbagai macam program pencegahan dan penanggulangan HIV AIDS, Namun kasus HIV AIDS tetap saja ditemukan. Hal tersebut dapat dilihat dari masih banyaknya masyarakat umum yang 
masih melakukan seks bebas dimana-mana, tentu hal tersebut menjadi penghambat pemerintah didalam melakukan upaya pencegahan dan penanggulangan HIV AIDS.

\section{Kesimpulan}

Berdasarkan hasil penelitian dan pembahasan, maka dapat ditarik simpulan bahwa Peran serta LAHA Sultra dalam penanganan PMKS khususnya dalam pendampingan terhadap ODHA di Kota Kendari idealnya mencakup peran sebagai fasilitator, broker, mediator, pembela, dan pelindung. Peran-peran tersebut sangat diharapkan oleh masyarakat karena: pertama, meningkatnya fenomena ODHA di Kota Kendari dalam beberapa tahun terakhir; kedua, masih kuatnya stigma terhadap ODHA yang berdampak buruk pada kehidupan dan kondisi kesejahteraan mereka; dan ketiga, masyarakat mempunyai tanggung jawab untuk bersama-sama pemerintah melakukan penyelenggaraan kesejahteraan sosial. Program Penanganan HIV-AIDS yaitu Meningkatkan Komunikasi,Informasi dan Edukasi HIV-AIDS,meningkatkan upaya penurunan prevalensi penyakit infeksi menular seksual,meningkatkan kewaspadaan universal di saranan pelayanan kesehatan

\section{Referensi}

Afriska, Mery. (2017).Pengawasan Terhadap Lembaga Swadaya Masyarakat (LSM) di Kabupaten Tulang Bawang Barat.Artikel Jurnal, Diakses dari jurnal.fh.unila.ac.id/index.php/han/article/download/856/738

Ahmadi, A., \& Widodo, S., ( 2013). Psikologi Belajar. Jakarta: Rineka Cipta. Anonim, 2018.Kendari Terbanyak Penderita HIV, Dinkes Sinyalir Sumbernya THM 'Esek-esek'. Sultra Antara News, 16 Agustus 2018,Diakses dari https://sultra.antaranews.com/b erita/.

Baroroh, Kiromim. (2009). Peran Lembaga Swadaya Masyarakat Terhadap Pemberdayaan Perempuan Melalui Pelatihan Life Skill (Studi Kasus di Lembaga Advokasi Pendidikan Yogyakarta). Jurnal DIMENSIA, Vol 3, No .1. 
Berry, David. (2003). Pokok-Pokok Pikiran dalam Sosiologi. Jakarta: PT. Raja Grafindo Persada.

Fitriani, Aida. (2013). Implementasi Program Rehabilitasi Sosial Bagi Anak Dan Wanita Korban Trafiking Di Rumah Perlindungan Sosial Wanita (RPSW) Jakarta.Jurnal Informasi, Vol. 18, No. 02, Tahun 2013, 159182.

Gafar, Affan. (2006). Politik Indonesia, Transisi Menuju Demokrasi.Yogyakarta: Pustaka Pelajar.

Herdiansah, Ari Ganjar. (2016). Peran Organisasi Masyarakat dan Lembaga Swadaya Masyarakat dalam Menopang Pembangunan di Indonesia.Open Journal Systems, Vol 1., No. 1, DOI: https://doi.org/10.24198/jsg.v1i 1.11185

Hikam, Muhammad AS. (1999).Demokrasi dan Civil Society. Jakarta: LP3ES.

Horton, B.P. dan Chester L. Hunt. (1999).Sosiologi. Jakarta: Erlangga.

Ismawan, Bambang, 2003. Partisipasi dan Dimensi Keswadayaan:

Pengalaman LSM Membangun Keswadayaan Masyarakat. Diakses dari www.ekonomirakyat.org/edisi 1

Kendaripos. (2016).Jumlah ODHA Meningkat, 118 Kasus HIV, 71 Positif Aids”, Kendari Pos, 1 Desember 2016. Diakses dari https://kendaripos.co.id/2016/...

Latifah, D., Mochamad, Z. dan Nandang, M. (2017). Peran Pendamping Bagi Orang Dengan HIV/AIDS (ODHA). Prosiding Ks: Riset \& PKM, 2 (3): 306-311.

Masudin, (2008).Kemitraan LSM Laha dan Pemerintah Kota Kendari dalam Upaya Penanggulangan HIV/AIDS di Kota Kendari Provinsi Sulawesi Tenggara. Tesis Magister. Yogyakarta: Universitas Gadjah Mada.

Narwoko,Suyanto J. Dwi, 2004.Sosiologi Teks Pengantar dan Terapan. Jakarta: Kencana Media Group.

Peraturan Pemerintah Nomor 39 Tahun 2012 Tentang Penyelenggaraan Kesejahteraan Sosial. 
Praja, Ageng N., (2009). Distorsi Peran Lembaga Swadaya Masyarakat dalam Perspektif Civil society di Kabupaten Grobogan.Tesis. Semarang: Program Pasca Sarjana Universitas Diponegoro.

Sanit, Arbi, (1995). Swadaya Politik Masyarakat. Jakarta: Rjawali.

Sarwono, Sarlito W., (2015). Teori-Teori Psikologi Sosial.Jakarta: Rajawali Pers.

Shaluhiyah, Zahroh, Syamsulhuda Budi Musthofa, \& Bagoes Widjanarko, 2015.Stigma Masyarakat terhadap Orang dengan HIV/AIDS.Jurnal Kesehatan Masyarakat Nasional, Vol. 9, No. 4, Mei 2015.

Suharto, Edi. (2018). Kebijakan Pengelolaan Data Program Rehabilitasi Sosial, Direktur Jenderal Rehabilitasi Sosial Kementerian Sosial Republik Indonesia, Disampaikan dalam Kegiatan Bimbingan Teknis Integrasi Layanan Rehabilitasi Sosial (IntelResos), Hotel Santika - Jakarta , 2 April 2018.

2010.Membangun Masyarakat Memberdayakan Masyarakat, Kajian Strategis Pembangunan Kesejahteraan Sosial dan Pekerjaan Sosial. Bandung: Refika Aditama.

Sultraantaranews. (2017). Dinkes Sultra: Kasus HIV/AIDS Terbanyak di Kendari.

Sultra Antara News, Selasa, 7 Agustus 2018. Diakses dari sultra.antaranews.com

Soekanto, Soerjono. (2013). Sosiologi Suatu Pengantar. Jakarta: PT. RajaGrafindo Persada.

Sundoko, Abdullah. (2001). Lembaga Swadaya Masyarakat. Semarang: Pustaka Pelajar.

Triani, Dini Dwi. (2018). Komunikasi Antarpribadi Konselor Dengan Odha

(Orang Dengan HIV/AIDS) dalam Memotivasi Hidup ODHA

di Klinik Voluntary Counselling and Testing (VCT) Kota Dumai.

Jurnal JOM FISIP, Vol. 5, edisi II, Juli-Desember, 1-15.

Walgito, Bimo. (2003).Psikologi Sosial.Edisi Revisi. Yogyakarta: Andi Offset. 